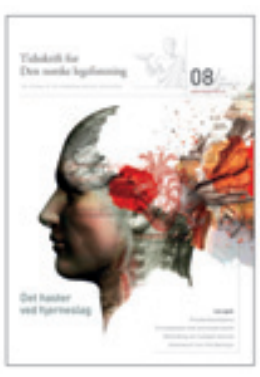

\section{Insidens av hjerneslag}

I Tidsskriftet nr. 8/2011 presenterer Halvor Næss og medarbeidere insidenstall for hjerneinfarkt i opptaksområdet for Haukeland universitetssykehus i 2007-09 (1). Et hovedbudskap i artikkelen er at den årlige insidensen er lav og under halvparten av insidensen som ble funnet i en befolkningsunders $ø$ kelse i Innherredsregionen i 1994-96 (2). Insidenstallene er basert på innlagte pasienter ved Haukeland universitetssykehus med diagnosen hjerneinfarkt, og totalinsidensen (råraten) sammenliknes med totalinsidensen (råraten) i Innherredsregionen hvor både innlagte og ikke innlagte pasienter ble registrert.

Skal man jamføre insidenstall i ulike populasjoner, er det aldersjusterte rater eller aldersspesifikke rater som gir en meningsfull sammenlikning. Imidlertid presenterer artikkelen insidensrater $i$ aldersgrupper som ikke lar seg sammenlikne med tidligere studier fra Skandinavia
(3). Sammenliknbare alderspesifikke insidensrater ville gitt oss muligheten til blant annet å studere om forskjellen som er observert, skyldes ulik alderssammensetning i de to populasjonene og om insidenstallene avviker like mye i alle aldersgrupper. Det kunne gitt oss viktig informasjon og tilbakemelding på om enkelte pasientgrupper ikke fanges opp og om det er holdepunkter for reelle forskjeller som har betydning for hvordan helsetjenesten skal innrette det forbyggende arbeidet. Slik insidenstallene er presentert, blir det vanskelig å studere årsaken til den regionale forskjellen som fremkommer.

\section{Hanne Ellekjær}

Avdeling for hjerneslag

St. Olavs hospital

Hanne Ellekjær (f. 1960) er dr.med. og spesialist $\mathrm{i}$ indremedisin og arbeider som overlege ved Avdeling for hjerneslag, St. Olavs hospital. Ingen oppgitte interessekonflikter.

Litteratur

1. Næss H, Waje-Andreassen U Brøgger J et al. Pasienter med akutt hjerneinfarkt innlagt i slagenhet. Tidsskr Nor Legeforen 2011; 131: 814-8.

2. Ellekjær H, Holmen J, Indredavik B et al. Epidemiology of stroke in Innherred, Norway, 1994 to 1996. Incidence and 30-day case-fatality. Stroke 1997; 28: $2180-4$

3. Ellekjær H, Selmer R. Hjerneslag - like mange rammes, men prognosen er bedre. Tidsskr Nor Lægeforen 2007; 127: 740-3.

\section{H. Næss svarer:}

Hanne Ellekjær har rett i sin kritikk. Svakheter ved insidensberegningen er diskutert i vår artikkel. Våre funn taler likevel sterkt for at det kan være store forskjeller når det gjelder insidens av hjerneinfarkt i Norge, og dette var et av budskapene vi ønsket å presentere i artikkelen. Vi håper derfor at artikkelen bidrar til interesse for nye insidensstudier av hjerneslag i Norge med like nøyaktige metoder som Hanne Ellekjær benyttet seg av i Innherred-undersøkelsen.

\section{Halvor Næss}

Nevrologisk avdeling

Haukeland universitetssykehus

Halvor Næss (f.1957) er spesialist i nevrologi og i indremedisin og er overlege ved Nevrologisk avdeling.

Ingen oppgitte interessekonflikter.

\section{RETTELSE}

Legeforeningen under okkupasjonen

Tidsskr Nor Legeforen 2011; 131: 1345

I denne notisen i Tidsskriftet nr. 13-14/2011 skulle det i siste setning stått: ... i det første frie Tidsskrift for Den norske lægeforening som kom ut 1.6. 1945. 